Threshold haemoglobin levels and the prognosis of stable coronary disease: meta-analysis

\title{
MOOSE flowchart
}

Potentially relevant cohort studies identified for HTA systematic review using MEDLINE and EMBASE search (1966 to November 2008); titles and abstracts retrieved

Studies investigating biomarkers: eGFR, fasting glucose, haemoglobin, total cholesterol,

LDL cholesterol, hsCRP, fibrinogen, lipoprotein a, apoliporotein A-I, apoliporotein B, homocysteine, brain natriuretic peptide, interleukin 6

$\mathrm{n}=14,723$

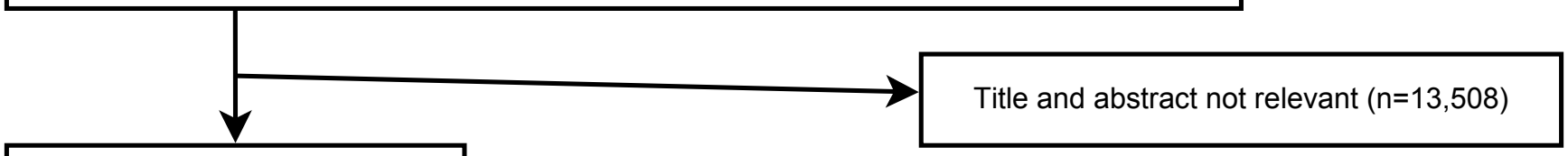

Full text of cohort studies retrieved for detailed evaluation $\mathrm{n}=1215$

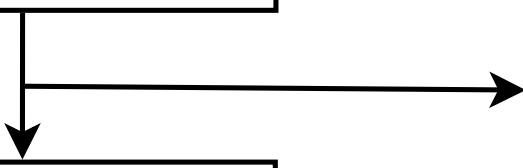

Cohort studies reported

in HTA systematic review $\mathrm{n}=390$

Cohort studies excluded:

No eligible biomarker $(n=97)$

Population not stable coronary disease $(n=391)$

Outcome not eligible $(n=41)$

No relative risk reported $(n=163)$

Not an original article (e.g. editorial, letter, review) $(n=66)$

Article not obtained $(n=38)$

Article not translated $(n=9)$

Article reported only mixed populations $(n=20)$

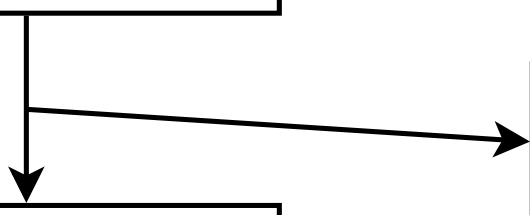

Cohort studies eligible for haemoglobin meta-analysis $\mathrm{n}=12$

No report of haemoglobin effect $(n=375)$

Follow-up less than 1 year $(n=3)$ :

Elisheva 2000 (1), McKechnie 2004 (2), Lee 2004 (3)

Cohort studies included in haemoglobin meta-analysis

$$
n=10
$$

Cohort studies excluded from meta-analysis because insufficient results reported $(n=2)$ :

Skinner 1999 (4) no mean or SD of haemoglobin levels Martin 1991 (5) no confidence interval for relative risk

The studies included in this meta-analysis are a subset of those reviewed in: Hemingway $\mathrm{H}$, Henriksson $\mathrm{M}$, Chen R, Damant J, Fitzpatrick N, Abrams K, et al. The effectiveness and cost-effectiveness of biomarkers for the prioritisation of patients awaiting coronary revascularisation: a systematic review and decision model. Health Technol Assess 2010;14(9). 


\section{References for excluded studies}

1. Elisheva S, Noya G, Simchen E, Galai N, Zitser-Gurevich Y, Braun D, et al. Sequential logistic models for 30 days mortality after CABG: pre-operative, intra-operative and post-operative experience - The Israeli CABG study (ISCAB). Eur J Epidemiol 2000; 16(6): 543-55.

2. McKechnie RS, Smith D, Montoye C, Kline-Rogers E, O'Donnell MJ, DeFranco AC, et al. Prognostic implication of anemia on in-hospital outcomes after percutaneous coronary intervention. Circulation 2004; 110(3): 271-7.

3. Lee CH, de Feyter P, Serruys PW, Saia F, Lemos PA, Goedhart D, et al. Beneficial effects of fluvastatin following percutaneous coronary intervention in patients with unstable and stable angina: results from the Lescol intervention prevention study (LIPS). Heart 2004; 90(10): 1156-61.

4. Skinner JS, Farrer M, Albers CJ, Neil HA, Adams PC. High apolipoprotein Al concentrations are associated with lower mortality and myocardial infarction five years after coronary artery bypass graft surgery. Heart 1999; 81(5): 488-94.

5. Martin JF, Bath PM, Burr ML. Influence of platelet size on outcome after myocardial infarction. Lancet 1991; 338(8780): 1409-11. 